\title{
Tyrosine Phosphorylation Site
}

National Cancer Institute

\section{Source}

National Cancer Institute. Tyrosine Phosphorylation Site. NCI Thesaurus. Code C14056.

It refers to amino acid tyrosine residue that was covalently modified by phosphate group (PO4-). ( $\mathrm{NCl})$ 